\title{
The density of barnyard grass affects photosynthesis and physiological characteristics of rice
}

\author{
X.L. WANG , Z.Y. ZHANG ${ }^{*, * *}$, X.M. XU**, and G. LI',+ \\ Institute of Plant Protection, Jiangsu Academy of Agricultural Sciences, Nanjing 210014, China* \\ College of Life Sciences, Nanjing Agricultural University, Nanjing 210095, China ${ }^{* *}$
}

\begin{abstract}
Barnyard grass (Echinochloa crus-galli) is a troublesome graminaceous weed infesting rice fields in the Yangtze River Basin, China. However, the effects of barnyard grass on rice root physiology are unclear. In this study, the effects of barnyard grass, planted at different densities (ranging from 2-8 plants $\mathrm{m}^{-2}$ ), on rice performance were evaluated, including chlorophyll fluorescence parameters, Rubisco activity, root oxidation activity, and the zeatin + zeatin riboside concentration. The results indicated that rice photosynthesis and physiological characteristics decreased as the density of barnyard grass increased. The rice net photosynthetic rate significantly declined and ranged between $17.3-10.5 \%$ compared with the control $\left(0\right.$ barnyard grass plants $\left.\mathrm{m}^{-2}\right)$. The results showed that rice grain yields decreased to $58 \%$ when barnyard grass was planted at a density of 8 plants $\mathrm{m}^{-2}$. We found that barnyard grass can reduce the Rubisco activity, leaf photosynthetic capacity, and energy conversion efficiency in rice, thus resulting in the reduced rice yield.
\end{abstract}

Additional key words: chlorophyll content; cytokinin; gas exchange; Oryza sativa; SPAD meter.

\section{Introduction}

Rice (Oryza sativa L.) is a staple food for more than half of the world population and is especially important in China. Factors including the development of a market-driven economy, declining labour resources, and improvements in grain quality (Chauhan 2012) have led to the large areas directly seeded with rice, which has resulted in shifts in weed populations and increases in the number of species (Matloob et al. 2015). Barnyard grass [Echinochloa crusgalli (L.) Beauv.] is a particularly competitive $\mathrm{C}_{4}$ weed in rice fields and has caused severe damage to rice production (Rao et al. 2007, Wang et al. 2013). Barnyard grass grows in large numbers and is closely related to rice at the genetic level (Chin 2001, Ottis and Talbert 2007). The competition between barnyard grass and rice is extremely high in rice fields. Many growth and development indices of rice can decrease sharply when barnyard grass density increases. These indices include rice height, tiller number, effective spikes, panicle number, 1000-grain mass, rice grain yield, etc. (Maun and Barrett 1986, Zhang et al. 2015). However, the heavy reliance on herbicides for weed control has resulted in the evolution and emergence of herbicideresistant weeds, weed species population shifts, and environmental pollution (Li et al. 2016).

Generally, researchers have concentrated on studying the influence of the aboveground morphology and yield of rice growing in the presence of barnyard grass. Plant growth is influenced by environmental conditions and genetic factors (Kimura et al. 2013). Alterations in structure and functional adjustment by crop species can occur in response to environmental changes, and the dynamic growth of crops can be considered a collection of many changes and adaptations (Hao 2013). Root systems are involved in the acquisition of nutrients and water, hormone synthesis, amino acid and organic compound synthesis, and plant anchorage (Yang et al. 2004). Root morphology and physiology play important roles in the aboveground growth and development of plants (Yang 2011), and the plant canopy affects photosynthesis and carbohydrate synthesis. The root and crown functions of a plant are complementary and rely on each other to meet the growth requirements and general functions of the system (Chen et al. 2011). However, it is not clear whether the key indices of root and plant physiological activity, such as changes in root oxidation activity (ROA), root sap bleeding, indole-3-acetic acid (IAA), and zeatin (Z) + zeatin riboside $(\mathrm{ZR})$ concentrations in the roots of rice

\footnotetext{
$\overline{\text { Received }} 12$ February 2018, accepted 15 October 2018.

${ }^{+}$Corresponding author; phone:86-25-84390335, e-mail: ligui@jaas.ac.cn

Abbreviations: $C_{\mathrm{i}}$ - intercellular $\mathrm{CO}_{2}$ concentration; $E$ - transpiration rate; ETR - electron transport rate; $\mathrm{F}_{\mathrm{v}} / \mathrm{F}_{\mathrm{m}}-$ maximal quantum yield of PSII photochemistry; $\mathrm{F}_{\mathrm{v}}{ }^{\prime} / \mathrm{F}_{\mathrm{m}}{ }^{\prime}-$ maximum photochemical efficiency of PSII in the light-adapted state; $g_{\mathrm{s}}-$ stomatal conductance; IAA - indole-3-acetic acid; NPQ - nonphotochemical quenching; $P_{\mathrm{N}}$ - net photosynthetic rate; $\mathrm{q}_{\mathrm{P}}$ - photochemical quenching coefficient; ROA - root oxidation activity; WUE - water-use efficiency; Z - zeatin; ZR - zeatin riboside.

Acknowledgements: This work was supported by the National Natural Science Foundation of China (31501656 and 31272080) and Jiangsu Agriculture Science and Technology Innovation Fund [CX(15)1004].
} 
(Samejima et al. 2004, Yang et al. 2004, Wu and Cheng 2014), affect rice yields where barnyard grass coexists. The objective of this study was to investigate the effect of different barnyard grass densities on the photosynthesis and physiological characteristics of rice. These results also provide a theoretical basis and practical guidance regarding the ecological regulation and management of barnyard grass in rice fields.

\section{Materials and methods}

Site description: Our experiment was conducted in 2015 and 2016 at an experimental rice field of the Institute of Plant Protection ( $\left.32^{\circ} 02^{\prime} 26.50^{\prime \prime} \mathrm{N}, 118^{\circ} 51^{\prime} 50.62^{\prime \prime} \mathrm{E}\right)$, Jiangsu Academy of Agricultural Sciences. The soil $\mathrm{pH}$ was 7.5 and it comprised $17.0 \mathrm{~g}$ (organic matter) $\mathrm{kg}^{-1}, 1.2 \mathrm{~g}$ (total $\left.\mathrm{N}\right)$ $\mathrm{kg}^{-1}, 40.0 \mathrm{mg}\left(\right.$ Olsen-P) $\mathrm{kg}^{-1}$, and $76.0 \mathrm{mg}$ (exchangeable $\mathrm{K}) \mathrm{kg}^{-1}$.

Experiment: An additive series experiment design were employed with fixed density of rice (180 plants $\left.\mathrm{m}^{-2}\right)$ planted in main plots, while four different densities of barnyard grass $\left(0,2,4\right.$, and 8 plants $\left.\mathrm{m}^{-2}\right)$ plants in subplots. Therefore, the densities during a prior test were set up systematically, and a simple linear relationship was found between densities of barnyard grass and the grain yield. The experiment comprised four treatments in a complete randomized block design with four replicates and a plot size of $3.6 \times 1.85 \mathrm{~m}$. Plots were separated by a $0.2-\mathrm{m}$ wide alley. The total experiment plot area was about $120 \mathrm{~m}^{2}$. The irrigation water was applied via pipelines. In order to achieve the desired weed densities, barnyard grass seeds were first sown in plastic pots $(22.5 \times 15 \times 7 \mathrm{~cm})$ filled with $1.5 \mathrm{~kg}$ of air-dried soil. Barnyard grass seedlings at the three-leaf stage were then carefully transplanted to the rice field. All other weeds in the field plots with the exception of barnyard grass were periodically manually removed. $\mathrm{N}$ (90 kg ha $\mathrm{kg}^{-1}$ as urea), $\mathrm{P}$ (30 kg ha ${ }^{-1}$ in form of single superphosphate), and $\mathrm{K}\left(45 \mathrm{~kg} \mathrm{ha}^{-1}\right.$ as $\left.\mathrm{KCl}\right)$ were applied prior to sowing. Urea was reapplied $20 \mathrm{~d}$ after sowing $\left(36 \mathrm{~kg} \mathrm{ha}^{-1}\right)$ and supplemented at the panicleinitiation stage $\left(54 \mathrm{~kg} \mathrm{ha}^{-1}\right)$.

Chlorophyll (Chl) relative content assay: Ten similarly sized plants were selected from each treatment for relative Chl-content measurements. A portable Chl meter (SPAD502, Minolta Corporation, Ltd., Osaka, Japan) was used to measure the relative $\mathrm{Chl}$ content (SPAD readings) of the second leaf from the top at the jointing stage and of the flag leaf at the heading and grain-filling stages, respectively. There were four replications per treatment.

Photosynthetic parameter measurements: Leaf gasexchange attributes were measured using a portable infrared gas-exchange analyser-based photosynthesis system ( $\mathrm{Li}$ 6400, LI-COR Inc., Lincoln, NE, USA) between 09:30 and $11: 15 \mathrm{~h}$ on a sunny day. At the jointing, heading, and grainfilling stages, six flag leaves of plants from each treatment were measured under following environmental conditions: PAR at the leaf surface was $1,200 \mu \mathrm{mol}$ (photon) $\mathrm{m}^{-2} \mathrm{~s}^{-1}$, the ambient $\mathrm{CO}_{2}$ concentration was $380 \mathrm{ppm}$, and the relative humidity (RH) was 40-60\%. Water-use efficiency (WUE) was calculated as the ratio between net photosynthetic rate $\left(P_{\mathrm{N}}\right)$ and transpiration rate $(E)$. There were four replications per treatment.

Chl fluorescence parameter assays: After determination of the gas-exchange parameters, the aforementioned flag leaves at the heading and grain-filling stages were dark-adapted for $30 \mathrm{~min}$ prior to being measured for Chl fluorescence using a Maxi Imaging-PAM system (Heinz Walz GmbH, Effeltrich, Germany). The following Chl fluorescence parameters were calculated: maximal quantum yield of PSII photochemistry $\left(\mathrm{F}_{\mathrm{v}} / \mathrm{F}_{\mathrm{m}}\right)$, maximum photochemical efficiency of PSII in the light-adapted state $\left(\mathrm{F}_{\mathrm{v}}{ }^{\prime} / \mathrm{F}_{\mathrm{m}}{ }^{\prime}\right)$, nonphotochemical quenching (NPQ), photochemical quenching $\left(\mathrm{q}_{\mathrm{p}}\right)$, and electron transport rate (ETR).

Root oxidation and Rubisco activity assays: Root oxidation was measured in accordance with the methods of Ramasamy et al. (1997). The roots were dug out with a spade (the soil volume taken for roots of each plant was around $25 \mathrm{~cm}$ in length $\times 20 \mathrm{~cm}$ in width $\times 20 \mathrm{~cm}$ in depth). The roots were carefully washed and detached from their nodal bases. At the heading and grain-filling stages, roots of four plants were used for each treatment. Rubisco extraction and activity measurements were performed as described by Zhang et al. (2013). Rubisco activity of fresh leaves was measured according to the declining absorbance at $340 \mathrm{~nm}$. Units of enzyme were calculated by using the formula: [units $\mathrm{g}^{-1}(\mathrm{FM})=\left(\Delta \mathrm{A}_{340}\right.$ min test $-\Delta \mathrm{A}_{340}$ min blank $) \times 3 \times$ dilution factor $/(4 \times 6.22 \times 0.1)]$. At the heading and grain-filling stages, four flag leaves of plants were used for each treatment. There were four replications per treatment.

Analysis of endogenous hormones in the bleeding sap: Root-bleeding sap was collected in accordance with the methods of Guan et al. (2014), with some modifications. Eight plants were sampled at the heading and grain-filling stages. Each plant was cut at an internode above the soil surface at 18:00 h; each cut was approximately $10 \mathrm{~cm}$ in length. The bleeding sap was collected next morning at 06:00 $\mathrm{h}$, and the mass of the sap was measured accordingly. The root-bleeding sap content was expressed as grams per $\mathrm{h}$ per root. The bleeding sap samples were stored at $-20^{\circ} \mathrm{C}$ until further analysis. There were four replications per treatment.

Indole-3-acetic acid (IAA), Z, and ZR were extracted and purified in accordance with the methods of Tarkowski et al. (2010). The extracts were analysed using an Agilent 1290 binary high-performance liquid chromatography (HPLC) system (Mississauga, Ontario, Canada) coupled with an $A B$ Sciex $Q T r a p^{\circledR} 6500$ tandem mass spectrometer (MS) (Foster City, CA, USA). Sample separation was carried out on an Agilent Zorbax SB-18 column $(150 \times$ $2.1 \mathrm{~mm}, 3.5 \mu \mathrm{m}$ ) at a flow rate of $0.3 \mathrm{~mL} \mathrm{~min}^{-1}$. The mobile phase A consisted of $20 \mathrm{mM} \mathrm{HCOOH}$ in water, and the mobile phase $\mathrm{B}$ consisted of acetonitrile (ACN). The $\mathrm{pH}$ of solvent $\mathrm{A}$ was adjusted to 5.0 with $\mathrm{NH}_{4} \mathrm{OH}$; the $\mathrm{pH}$ of 
solvent B with ACN. The following elution profile was used: an isocratic step at $12 \% \mathrm{~B}$ for 15 min preceded a continuous linear increase from 12 to $17 \% \mathrm{~B}$ for $15 \mathrm{~min}$. At the end of the increase, a washing step at 100\% B occurred (for $16 \mathrm{~min}$ ), after which the column was equilibrated to the initial conditions for $10 \mathrm{~min}$. The injection volume was $2 \mu \mathrm{L}$, and the column temperature was maintained at $30^{\circ} \mathrm{C}$. All samples were analysed in positive ion mode. The wavelength of the UV detector was set at $254 \mathrm{~nm}$.

Yield and yield component assays: The rice was harvested at full maturity, and the grain yield was determined for all plants from within a $1-\mathrm{m}^{2}$ site (excluding border plants) at each plot. The yield components, i.e. the number of panicles per square metre, grain mass, and the percentage of filled grains, were determined for ten randomly sampled plants (excluding the plants along the borders) from each plot. The percentage of filled grains was defined as the percentage of the filled grain of the total number of spikelets. The number of spikelets per panicle was calculated from the grain yield, grain mass, and percentage of filled grains, i.e., the number of spikelets per panicle $=$ grain yield per square metre/(number of panicles per square metre $\times 1,000$-grain mass $\times$ percentage of filled grains).

Statistical analysis: One-way analysis of variance ( $A N O V A$ ) was carried out using the SPSS software package (SPSS 18.0 for Windows, Chicago, IL, USA) for all sets of data. The figures were constructed with Origin 8.0 software (OriginLab Inc., Northampton, MA, USA). Statistical differences were analysed using one-way $A N O V A$, and the means for each treatment were compared by Duncan's test at $\alpha=0.05$. The data were expressed as the means \pm standard errors (SEs).

\section{Results}

SPAD readings and leaf gas exchange: The presence of barnyard grass reduced values of the SPAD readings in rice and the photosynthetic parameters (Table 1). Compared with that of the control (41.94 and 41.28, SPAD Chl relative contents in the heading stage and in grain-filling stage, respectively), the SPAD readings significantly decreased from $8.1 \%$ (38.53) to $4.0 \%$ (40.28) at the heading stage and from $9.4 \%(37.41)$ to $5.7 \%(38.94)$ at the grain-filling stage when the weed density was 2 , 4 , or 8 plants $\mathrm{m}^{-2}$; however, no significant differences at the jointing stage were observed. Weed competition also resulted in a considerable decline in leaf gas-exchange parameters (Table 1). Specifically, under the weed density of 8 plants $\mathrm{m}^{-2}$, the $P_{\mathrm{N}}$ rate significantly decreased by $9.7 \%$ at the jointing stage and by $21.7 \%$ at the heading stage. Furthermore, at the jointing stage, the intercellular $\mathrm{CO}_{2}$ $\left(C_{\mathrm{i}}\right)$ did not significantly differ under weedy conditions. However, at the heading stage, stomatal conductance $\left(g_{\mathrm{s}}\right)$ and $C_{\mathrm{i}}$ significantly differed under the weed density of 8 plants $\mathrm{m}^{-2}$. Additionally, when the weed density was 4 or 8 plants $\mathrm{m}^{-2}$, the $P_{\mathrm{N}}, g_{\mathrm{s}}$, and $C_{\mathrm{i}}$ decreased significantly from 17.3 to $10.5,17.5$ to 15 , and 2.6 to $2.2 \%$, respectively, at the grain-filling stage.

Chl fluorescence parameters: Weed competition adversely affected $\mathrm{Chl}$ fluorescence parameters, which is clearly indicated in Table 2. At the heading stage, the $\mathrm{F}_{\mathrm{v}}{ }^{\prime} / \mathrm{F}_{\mathrm{m}}{ }^{\prime}$ in the leaves under the control conditions $\left(0\right.$ plants $\left.\mathrm{m}^{-2}\right)$ was approximately 0.507 but was only approximately 0.477 and 0.449 under weed densities of 4 or 8 plants $\mathrm{m}^{-2}$, respectively. The $\mathrm{q}_{\mathrm{p}}$ ranged from 0.705 to 0.668 for weed densities ranging from $4-8$ plants $\mathrm{m}^{-2}$, whereas the $\mathrm{q}_{\mathrm{p}}$ under the control conditions was 0.730 . The ETR values were 37.3 and 35.1 when the weed density was 4 or 8 plants $\mathrm{m}^{-2}$,

Table 1. Effects of different barnyard grass densities on photosynthetic gas-exchange parameters of rice at different growth stages. Data represent means \pm SE of four replicates. Different letters indicate significant differences $(p<0.05)$ between lines according to Duncan's test. $C_{\mathrm{i}}$ - intercellular $\mathrm{CO}_{2}$ concentration; $g_{\mathrm{s}}-$ stomatal conductance; $P_{\mathrm{N}}-$ net photosynthetic rate; WUE - water-use efficiency.

\begin{tabular}{|c|c|c|c|c|c|c|}
\hline Growth stage & $\begin{array}{l}\text { Density } \\
\text { [plants } \mathrm{m}^{-2} \text { ] }\end{array}$ & $\begin{array}{l}\text { Chlorophyll relative } \\
\text { content } \\
\text { SPAD readings }\end{array}$ & $\begin{array}{l}P_{\mathrm{N}} \\
{\left[\mu \mathrm{mol}\left(\mathrm{CO}_{2}\right) \mathrm{m}^{-2} \mathrm{~s}^{-1}\right]}\end{array}$ & $\begin{array}{l}g_{\mathrm{s}} \\
{\left[\mu \mathrm{mol}\left(\mathrm{H}_{2} \mathrm{O}\right) \mathrm{m}^{-2} \mathrm{~s}^{-1}\right]}\end{array}$ & $\begin{array}{l}C_{\mathrm{i}} \\
{\left[\mu \mathrm{mol}\left(\mathrm{CO}_{2}\right) \mathrm{mol}^{-1}\right]}\end{array}$ & WUE \\
\hline \multirow[t]{4}{*}{ Jointing } & 0 & $41.44 \pm 2.08^{\mathrm{a}}$ & $26.9 \pm 1.1^{\mathrm{a}}$ & $0.97 \pm 0.08^{\mathrm{a}}$ & $316.0 \pm 3.6^{\mathrm{a}}$ & $2.33 \pm 0.02^{\mathrm{a}}$ \\
\hline & 2 & $42.61 \pm 3.13^{\mathrm{a}}$ & $25.3 \pm 2.1^{\mathrm{ab}}$ & $0.82 \pm 0.05^{\mathrm{b}}$ & $319.4 \pm 6.3^{\mathrm{a}}$ & $2.25 \pm 0.13^{\mathrm{a}}$ \\
\hline & 4 & $42.99 \pm 2.46^{\mathrm{a}}$ & $25.0 \pm 1.2^{\mathrm{ab}}$ & $0.86 \pm 0.06^{\mathrm{b}}$ & $317.3 \pm 0.9^{\mathrm{a}}$ & $2.15 \pm 0.06^{\mathrm{b}}$ \\
\hline & 8 & $41.51 \pm 2.84^{\mathrm{a}}$ & $24.3 \pm 2.5^{\mathrm{b}}$ & $0.80 \pm 0.08^{\mathrm{b}}$ & $316.7 \pm 5.0^{\mathrm{a}}$ & $2.05 \pm 0.13^{b}$ \\
\hline \multirow[t]{4}{*}{ Heading } & 0 & $41.94 \pm 0.75^{\mathrm{a}}$ & $24.3 \pm 1.0^{\mathrm{a}}$ & $0.46 \pm 0.04^{\mathrm{a}}$ & $275.9 \pm 9.1^{\mathrm{a}}$ & $3.20 \pm 0.22^{\mathrm{a}}$ \\
\hline & 2 & $40.28 \pm 0.95^{\mathrm{b}}$ & $23.6 \pm 0.8^{\mathrm{a}}$ & $0.46 \pm 0.03^{\mathrm{a}}$ & $280.3 \pm 7.0^{\mathrm{a}}$ & $3.00 \pm 0.21^{\mathrm{ab}}$ \\
\hline & 4 & $40.27 \pm 0.97^{b}$ & $24.4 \pm 0.9^{\mathrm{a}}$ & $0.46 \pm 0.02^{\mathrm{a}}$ & $276.8 \pm 1.7^{\mathrm{a}}$ & $2.89 \pm 0.05^{\mathrm{b}}$ \\
\hline & 8 & $38.53 \pm 1.24^{\mathrm{c}}$ & $19.1 \pm 1.8^{\mathrm{b}}$ & $0.31 \pm 0.07^{\mathrm{b}}$ & $258.5 \pm 16.5^{\mathrm{b}}$ & $3.07 \pm 0.36^{\mathrm{ab}}$ \\
\hline \multirow[t]{4}{*}{ Grain-filling } & 0 & $41.28 \pm 2.13^{\mathrm{a}}$ & $19.1 \pm 1.4^{\mathrm{a}}$ & $0.40 \pm 0.04^{\mathrm{a}}$ & $298.9 \pm 3.5^{\mathrm{a}}$ & $4.53 \pm 0.29^{\mathrm{a}}$ \\
\hline & 2 & $38.68 \pm 1.68^{\mathrm{b}}$ & $18.1 \pm 0.7^{\mathrm{ab}}$ & $0.36 \pm 0.02^{\mathrm{ab}}$ & $296.9 \pm 3.4^{\mathrm{ab}}$ & $4.13 \pm 0.11^{\mathrm{b}}$ \\
\hline & 4 & $38.94 \pm 1.38^{\mathrm{b}}$ & $17.1 \pm 1.6^{\mathrm{bc}}$ & $0.33 \pm 0.04^{\mathrm{b}}$ & $292.3 \pm 3.5^{\mathrm{bc}}$ & $3.61 \pm 0.13^{\mathrm{c}}$ \\
\hline & 8 & $37.41 \pm 1.25^{\mathrm{c}}$ & $15.8 \pm 2.7^{\mathrm{c}}$ & $0.34 \pm 0.08^{\mathrm{b}}$ & $291.1 \pm 7.8^{\mathrm{c}}$ & $2.91 \pm 0.13^{\mathrm{d}}$ \\
\hline
\end{tabular}


Table 2. Effects of different barnyard grass densities on the chlorophyll fluorescence parameters of rice at the heading and grainfilling stages. Data represent means \pm SE of four replicates. The means followed by the same letter for the same parameter do not significantly differ at $p>0.05$. In addition, different letters indicate significant differences at $p<0.05$. ETR - electron transport rate; $\mathrm{F}_{\mathrm{v}} / \mathrm{F}_{\mathrm{m}}$ - maximal quantum yield of PSII photochemistry; $\mathrm{F}_{\mathrm{v}}{ }^{\prime} / \mathrm{F}_{\mathrm{m}}{ }^{\prime}-$ maximum photochemical efficiency of PSII in the light-adapted state; $\mathrm{NPQ}$ - nonphotochemical quenching; $\mathrm{q}_{\mathrm{P}}$ - photochemical quenching coefficient.

\begin{tabular}{lllllll}
\hline Growth stage & $\begin{array}{l}\text { Density } \\
{\left[\text { plants } \mathrm{m}^{-2}\right]}\end{array}$ & $\mathrm{F}_{\mathrm{v}} / \mathrm{F}_{\mathrm{m}}$ & $\mathrm{F}_{\mathrm{v}}{ }^{\prime} \mathrm{F}_{\mathrm{m}}{ }^{\prime}$ & $\mathrm{NPQ}$ & $\mathrm{q}_{\mathrm{P}}$ & $\mathrm{ETR}$ \\
\hline Heading stage & 0 & $0.816 \pm 0.005^{\mathrm{a}}$ & $0.507 \pm 0.011^{\mathrm{a}}$ & $0.239 \pm 0.015^{\mathrm{b}}$ & $0.730 \pm 0.012^{\mathrm{a}}$ & $39.6 \pm 0.8^{\mathrm{a}}$ \\
& 2 & $0.815 \pm 0.014^{\mathrm{a}}$ & $0.493 \pm 0.023^{\mathrm{ab}}$ & $0.241 \pm 0.043^{\mathrm{b}}$ & $0.712 \pm 0.034^{\mathrm{ab}}$ & $38.6 \pm 1.8^{\mathrm{ab}}$ \\
& 4 & $0.804 \pm 0.012^{\mathrm{b}}$ & $0.477 \pm 0.019^{\mathrm{b}}$ & $0.243 \pm 0.028^{\mathrm{b}}$ & $0.705 \pm 0.020^{\mathrm{b}}$ & $37.3 \pm 1.4^{\mathrm{b}}$ \\
& 8 & $0.819 \pm 0.018^{\mathrm{a}}$ & $0.449 \pm 0.030^{\mathrm{c}}$ & $0.302 \pm 0.059^{\mathrm{a}}$ & $0.668 \pm 0.036^{\mathrm{c}}$ & $35.1 \pm 2.3^{\mathrm{c}}$ \\
Grain-filling & 0 & $0.791 \pm 0.004^{\mathrm{b}}$ & $0.445 \pm 0.011^{\mathrm{a}}$ & $0.331 \pm 0.022^{\mathrm{b}}$ & $0.719 \pm 0.009^{\mathrm{a}}$ & $34.8 \pm 0.8^{\mathrm{a}}$ \\
stage & & & & & & \\
& 2 & $0.803 \pm 0.006^{\mathrm{a}}$ & $0.427 \pm 0.013^{\mathrm{b}}$ & $0.376 \pm 0.036^{\mathrm{a}}$ & $0.690 \pm 0.015^{\mathrm{b}}$ & $33.4 \pm 1.1^{\mathrm{b}}$ \\
& 4 & $0.802 \pm 0.009^{\mathrm{a}}$ & $0.454 \pm 0.024^{\mathrm{a}}$ & $0.269 \pm 0.042^{\mathrm{c}}$ & $0.689 \pm 0.034^{\mathrm{b}}$ & $35.5 \pm 1.8^{\mathrm{a}}$ \\
& 8 & $0.787 \pm 0.017^{\mathrm{b}}$ & $0.422 \pm 0.029^{\mathrm{b}}$ & $0.322 \pm 0.054^{\mathrm{b}}$ & $0.681 \pm 0.026^{\mathrm{b}}$ & $33.0 \pm 2.3^{\mathrm{b}}$ \\
\hline
\end{tabular}

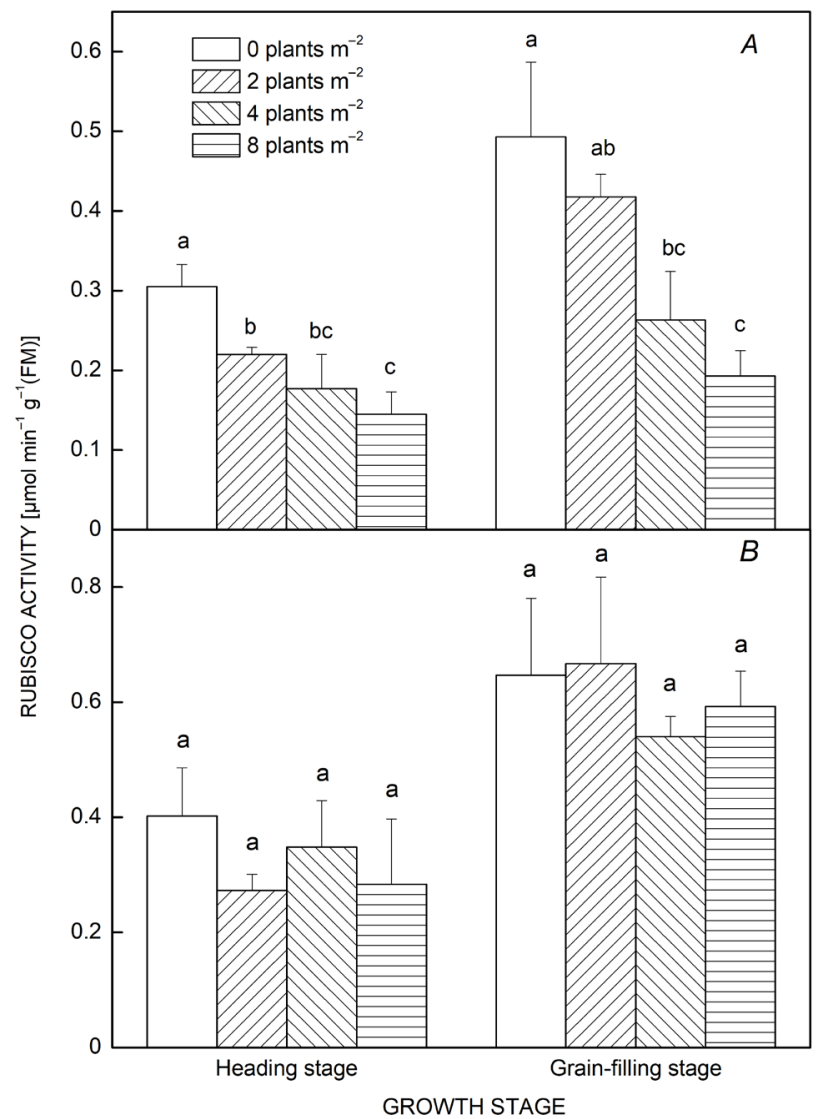

Fig. 1. Effects of different barnyard grass densities on initial Rubisco activity $(A)$ and total Rubisco activity $(B)$ of rice at the heading and grain-filling stages. Data represent means \pm SE of four replicates. The means followed by the same letter within the Rubisco activity do not significantly at $p>0.05$. In addition, different letters indicate significant differences at $p<0.05$.

whereas the ETR value was 39.6 for the control. In addition, when the weed density was 4 or 8 plants $\mathrm{m}^{-2}$, the

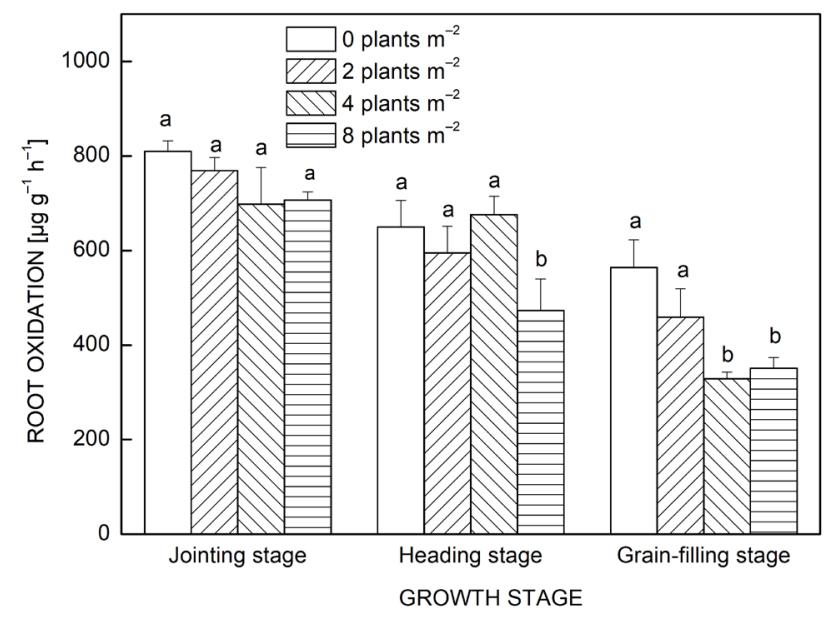

Fig. 2. Effects of different barnyard grass densities on the root oxidation of rice at different stages. Data represent means $\pm \mathrm{SE}$ of four replicates. The means followed by the same letter within the root oxidation do not significantly differ at $p>0.05$. In addition, different letters indicate significant differences at $p<0.05$.

$\mathrm{F}_{\mathrm{v}}{ }^{\prime} / \mathrm{F}_{\mathrm{m}}{ }^{\prime}, \mathrm{q}_{\mathrm{p}}$, and ETR significantly decreased from 11.4 to $5.9,8.5$ to 3.4 , and 11.4 to $5.8 \%$, respectively. However, compared with that of the control, the NPQ gradually increased as the barnyard grass density increased (Table 2). At the grain-filling stage, barnyard grass density had an irregular impact on the parameters of Chl fluorescence.

Rubisco activity decreased gradually in rice at both the heading and grain-filling stages, and the initial activity reached its lowest value when weed density was 8 plants $\mathrm{m}^{-2}$ (Fig. 1). However, the total Rubisco enzyme activity did not significantly differ from that of the control. Specifically, at the heading stage, when the weed density reached 2 plants $\mathrm{m}^{-2}$ (or greater), the initial activity significantly decreased from 0.220 to $0.144 \mu \mathrm{mol} \mathrm{min} \mathrm{m}^{-1}$ $\mathrm{g}^{-1}$ (fresh mass, FM), whereas the activity of the control was $0.310 \mu \mathrm{mol} \mathrm{min} \mathrm{m}^{-1} \mathrm{~g}^{-1}(\mathrm{FM})$. At the grain-filling stage, 


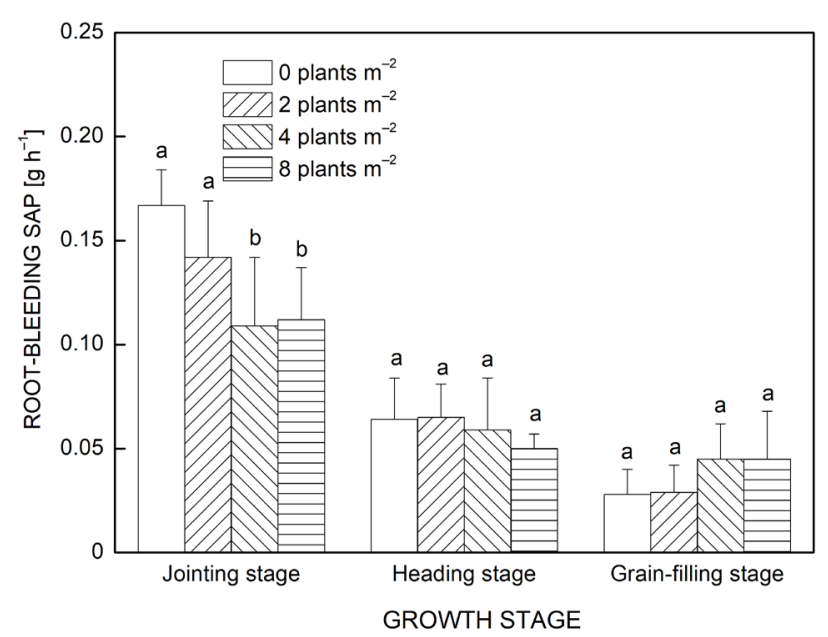

Fig. 3. Effects of different barnyard grass densities on the root-bleeding sap in the roots of rice at different stages. Data represent means $\pm \mathrm{SE}$ of four replicates. The means followed by the same letter within the root-bleeding sap do not significantly differ at $p>0.05$. In addition, different letters indicate significant differences at $p<0.05$.

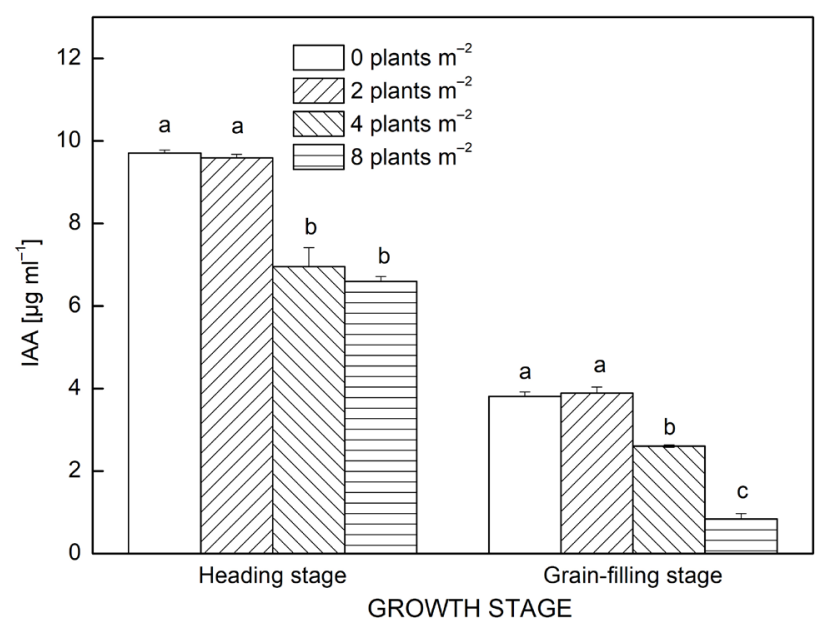

Fig. 4. Effects of different barnyard grass densities on IAA concentrations in the roots of rice at different stages. Data represent means \pm SE of four replicates. The means followed by the same letter within IAA concentrations do not significantly differ at $p>0.05$. In addition, different letters indicate significant differences at $p<0.05$. IAA - indole-3-acetic acid.

when the weed density was 4 or 8 plants $\mathrm{m}^{-2}$, the initial activity significantly decreased from 0.418 to $0.193 \mu \mathrm{mol}$ $\min ^{-1} \mathrm{~g}^{-1}(\mathrm{FM})$, whereas the activity of the control was $0.493 \mu \mathrm{mol} \mathrm{min} \mathrm{m}^{-1} \mathrm{~g}^{-1}(\mathrm{FM})$.

Root oxidation decreased with the ongoing plant development, especially at the grain-filling stage (Fig. 2). No significant differences between the treatment and control plants were observed at the jointing stage. However, the root oxidation significantly decreased when the density was 8 plants $\mathrm{m}^{-2}$ at the heading stage and 4 or 8 plants $\mathrm{m}^{-2}$ at the grain-filling stage.

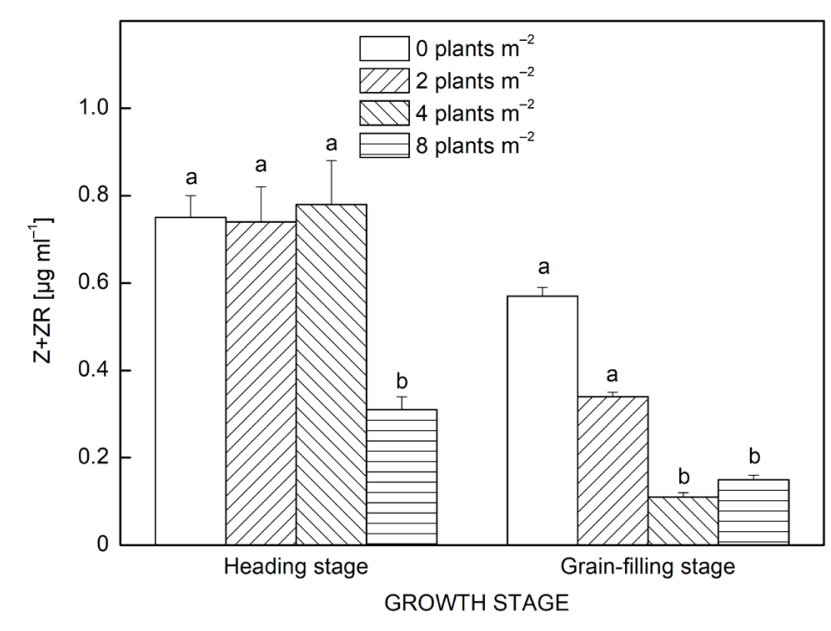

Fig. 5. Effects of different barnyard grass densities on Z+ZR concentrations in the roots of rice at different stages. Data represent means $\pm \mathrm{SE}$ of four replicates. The means followed by the same letter within $\mathrm{Z}+\mathrm{ZR}$ concentrations do not significantly differ at $p>0.05$. In addition, different letters indicate significant differences at $p<0.05$. Z - zeatin; ZR - zeatin riboside.

Root-bleeding sap and endogenous hormones: Weed competition substantially reduced the root-bleeding sap content (Fig. 3), and endogenous hormone concentrations (Figs. 4,5 ). When the weed density was 4 or 8 plants $\mathrm{m}^{-2}$, the root-bleeding sap flow significantly decreased from 34.7 to $32.9 \%$ at the jointing stage, but no significant differences in root-bleeding sap flow were observed at the heading or grain-filling stage. Nevertheless, the endogenous hormone contents in the root-bleeding sap decreased considerably during those stages. The IAA concentrations and the $\mathrm{Z}+\mathrm{ZR}$ concentration declined at both stages. Specifically, compared with that under the control conditions, the IAA concentration significantly decreased in the bleeding sap under weed densities of 4 or 8 plants $\mathrm{m}^{-2}$ at both stages. The $\mathrm{Z}+\mathrm{ZR}$ concentration significantly decreased at the heading stage when the weed density was 8 plants $\mathrm{m}^{-2}$ and at the grain-filling stage when the weed density was greater than 2 plants $\mathrm{m}^{-2}$.

Yield and yield components: Overall, the rice yield parameters were lower under weedy conditions than those under weed-free conditions (Table 3 ). On average, the rice grain yield significantly decreased from 8,718 to $4,316 \mathrm{~kg}$ $\mathrm{ha}^{-1}$. Weed competition significantly reduced the number of effective spikelets and the grain number per spike; the percentage decreases ranged from 24 to $6.7 \%$ and from 43.1 to $14.6 \%$, respectively. In addition, the 1,000-grain mass was also significantly affected by weed competition. Although no significant differences in 1,000-grain mass were observed at the lowest density of 2 plants $\mathrm{m}^{-2}$, it significantly decreased from 26.81 to $25.97 \mathrm{~g}$ at higher densities. The seed-setting rate decreased gradually as the weed density increased. The lowest seed-setting rate $(81.7 \%)$ occurred at a weed density of 8 plants $\mathrm{m}^{-2}$, whereas that of the control was $92.9 \%$. 
Table 3. Effects of different barnyard grass densities on the yield and yield components of rice. Data represent means $\pm \mathrm{SE}$ of four replicates. The means followed by the same letter within the same parameter do not significantly differ at $p>0.05$. In addition, different letters indicate significant differences at $p<0.05$.

\begin{tabular}{llllll}
\hline $\begin{array}{l}\text { Density } \\
\left.\text { [plants } \mathrm{m}^{-2}\right]\end{array}$ & $\begin{array}{l}\text { Number of effective } \\
\text { spikelets }\end{array}$ & $\begin{array}{l}\text { Grain number per } \\
\text { spike }\end{array}$ & $\begin{array}{l}\text { Seed setting rate } \\
{[\%]}\end{array}$ & $\begin{array}{l}1,000 \text {-grain mass Grain yield } \\
{[\mathrm{g}]}\end{array}$ & {$\left[\mathrm{kg} \mathrm{ha}^{-1}\right]$} \\
\hline 0 & $313 \pm 14^{\mathrm{a}}$ & $137 \pm 11^{\mathrm{a}}$ & $92.87 \pm 5.00^{\mathrm{a}}$ & $27.61 \pm 0.37^{\mathrm{a}}$ & $10,280 \pm 558^{\mathrm{a}}$ \\
2 & $292 \pm 9^{\mathrm{b}}$ & $117 \pm 10^{\mathrm{b}}$ & $93.11 \pm 3.95^{\mathrm{a}}$ & $27.69 \pm 0.30^{\mathrm{a}}$ & $8,718 \pm 430^{\mathrm{b}}$ \\
4 & $279 \pm 20^{\mathrm{c}}$ & $105 \pm 8^{\mathrm{c}}$ & $89.21 \pm 7.88^{\mathrm{a}}$ & $26.81 \pm 0.28^{\mathrm{b}}$ & $7,792 \pm 570^{\mathrm{c}}$ \\
8 & $238 \pm 13^{\mathrm{d}}$ & $78 \pm 13^{\mathrm{d}}$ & $81.74 \pm 9.20^{\mathrm{b}}$ & $25.97 \pm 0.32^{\mathrm{c}}$ & $4,316 \pm 325^{\mathrm{d}}$ \\
\hline
\end{tabular}

\section{Discussion}

Competition with weeds often results in light, water, nutrient, and crop yield losses in the field (Page et al. 2010). Yield losses can range from $4.5-93 \%$ depending on the density of both the crop species and weeds (Chauhan and Johnson 2010, Fickett et al. 2013, Safdar et al. 2015). Barnyard grass at a density of 9 plants $\mathrm{m}^{-2}$ can reduce rice yields by approximately 57\% (Maun and Barrett 1986). In this study, rice yield losses ranged from 15.2$58 \%$, depending on the barnyard grass density. Previous studies have considerably improved the knowledge of root structure and function, research techniques for root studies, root growth and metabolism under stress, root-rhizosphere interactions, and the roles of roots in plant development (Waisel et al. 2002). Root growth stress can be classified as water stress (Sharp and LeNoble 2002), salinity stress (Khan and Panda 2008), or aluminium stress (Shen et al. 2005). Furthermore, the impact of weeds on crops can also be considered a type of stress. Light signals, such as a low red to far-red ratio reflected from stem and leaf surfaces of neighboring weeds, can trigger a shade-avoidance response in crop plants, such as stem elongation, reduction in stem diameter, and a reduction in shoot and root biomass (Afifi and Swanton 2011). Additionally, root competition may be the primary mechanism that determines competitive outcomes between rice and Echinochloa species (Gibson et al. 1999); however, simultaneous studies of root and shoot growth are still needed (Chauhan and Johnson 2010).

Root oxidation activity (ROA) has been considered an important index of root physiological activity (Samejima et al. 2004). ROA is closely associated with rice aboveground biomass, leaf photosynthetic rate during the grain-filling period, and high grain yields ( $\mathrm{Wu}$ and Cheng 2014). Jungle rice [Echinochloa colona (L.) Link] and ludwigia [Ludwigia hyssopifolia (G. Don) Exell] can reduce the root dry mass of rice (Chauhan and Johnson 2010). Our results indicated that root activity decreased significantly from $41.7-18.6 \%$ at the grain-filling stage as barnyard grass density increased (Fig. 2).

Many studies have demonstrated that, during the grain-filling stage, the $\mathrm{Z}+\mathrm{ZR}$ content within rice roots is significantly correlated with both the division rate of endosperm cells and the grain-filling rate (Yang et al. 2004). Our results indicated that the IAA concentration and the Z+ZR concentration decreased at both the heading and grain-filling stages (Figs. 4, 5). Shu et al. (2004) reported that a rapid decrease in the $\mathrm{Z}+\mathrm{ZR}$ concentration and an increase in the abscisic acid concentration in both the roots and leaves of rice coincided with a decrease in the rice leaf photosynthetic rate during the grain-filling period. Our results indicated that SPAD readings significantly decreased from 9.4 to $5.3 \%$ at the grain-filling stage. Additionally, when the weed density was 4 or 8 plants $\mathrm{m}^{-2}$, the $P_{\mathrm{N}}, g_{\mathrm{s}}$, and $C_{\mathrm{i}}$ decreased significantly at the grainfilling stage. In summary, the results of the comprehensive analysis in this study indicate that competition from barnyard grass can reduce the photosynthetic capacity, Rubisco activity, ROA, and Z+ZR concentration in rice, ultimately leading to reduced rice yields.

\section{References}

Afifi M., Swanton C.: Maize seed and stem roots differ in response to neighbouring weeds. - Weed Res. 51: 442-450, 2011.

Chauhan B.S.: Weed ecology and weed management strategies for dry-seeded rice in Asia. - Weed Technol. 26: 1-13, 2012.

Chauhan B.S., Johnson D.E.: Relative importance of shoot and root competition in dry-seeded rice growing with junglerice (Echinochloa colona) and ludwigia (Ludwigia hyssopifolia). - Weed Sci. 58: 295-299, 2010.

Chen X.Y., Gao Z.H., Luo P.Y.: [Relationship between root and shoot of plants.] - Plant Physiol. Commun. 41: 555-562, 2011. [In Chinese]

Chin D.V.: Biology and management of barnyardgrass, red sprangletop and weedy rice. - Weed Biol. Manag. 1: 37-41, 2001.

Fickett N.D., Boerboom C.M., Stoltenberg D.E.: Predicted corn yield loss due to weed competition prior to postemergence herbicide application on Wisconsin farms. - Weed Technol. 27: 54-62, 2013.

Gibson K.D., Foin T.C., Hill J.E.: The relative importance of root and shoot competition between water-seeded rice and Echinochloa phyllopogon. - Weed Res. 39: 181-190, 1999.

Guan D., Al-Kaisi M.M., Zhang Y. et al.: Tillage practices affect biomass and grain yield through regulating root growth, rootbleeding sap and nutrients uptake in summer maize. - Field Crop Res. 157: 89-97, 2014.

Hao W.P.: [Influence of Water Stress and Rewatering on Maize WUE and Compensation Effects.] Pp. 32-34. Chinese Academy of Agricultural Sciences, Beijing 2013. [In Chinese]

Khan M.H., Panda S.K.: Alterations in root lipid peroxidation and antioxidative responses in two rice cultivars under $\mathrm{NaCl}-$ salinity stress. - Acta Physiol. Plant. 30: 81-89, 2008.

Kimura M.K., Kabeya D., Saito T. et al.: Effects of genetic and environmental factors on clonal reproduction in old-growth natural populations of Cryptomeria japonica. - Forest Ecol. 
Manag. 304: 10-19, 2013.

Li G., Xu M.F., Chen L.P. et al.: A novel EcGH3 gene with a different expression pattern in quinclorac-resistant and susceptible barnyard grass (Echinochloa crus-galli). - Plant Gene 5: 65-70, 2016.

Matloob A., Khaliq A., Chauhan B.S.: Weeds of direct-seeded rice in Asia: problems and opportunities. - Adv. Agron. 130: 291-336, 2015.

Maun M.A., Barrett S.C.H.: The biology of Canadian weeds. 77. Echinochloa crus-galli (L.) Beauv. - Can. J. Plant Sci. 66: 739-759, 1986.

Ottis B.V., Talbert R.E.: Barnyardgrass (Echinochloa crus-galli) control and rice density effects on rice yield components. Weed Technol. 21: 110-118, 2007.

Page E.R., Tollenaar M., Lee E.A. et al.: Shade avoidance: an integral component of crop-weed competition. - Weed Res. 50: $281-288,2010$.

Ramasamy S., ten Berge H.F.M., Purushothaman S.: Yield formation in rice in response to drainage and nitrogen application. - Field Crop Res. 51: 65-82, 1997.

Rao A.N., Johnson D.E., Sivaprasad B. et al.: Weed management in direct-seeded rice. - Adv. Agron. 93: 153-255, 2007.

Safdar M.E., Tanveer A., Khaliq A. et al.: Yield losses in maize (Zea mays) infested with parthenium weed (Parthenium hysterophorus L.). - Crop Prot. 70: 77-82, 2015.

Samejima H., Kondo M., Ito O. et al.: Root-shoot interaction as a limiting factor of biomass productivity in new tropical rice lines. - Soil Sci. Plant Nutr. 50: 545-554, 2004.

Sharp R.E., LeNoble M.E.: ABA, ethylene and the control of shoot and root growth under water stress. - J. Exp. Bot. 53: 33-37, 2002

Shen H., He L.F., Sasaki T. et al.: Citrate secretion coupled with the modulation of soybean root tip under aluminum stress. Up-regulation of transcription, translation, and threonineoriented phosphorylation of plasma membrane $\mathrm{H}^{+}$-ATPase.
- Plant Physiol. 138: 287-296, 2005.

Shu Q.C., Rong X.Z., Wei L. et al.: The involvement of cytokinin and abscisic acid levels in roots in the regulation of photosynthesis function in flag leaves during grain filling in super high-yielding rice (Oryza sativa). - J. Agron. Crop Sci. 190: 73-80, 2004.

Tarkowski P., Václavíková K., Novák O. et al.: Analysis of 2-methylthio-derivatives of isoprenoid cytokinins by liquid chromatography-tandem mass spectrometry. - Anal. Chim. Acta 680: 86-91, 2010.

Waisel Y., Eshel A., Kafkafi U.: Plant Roots, the Hidden Half. Pp. 1120. Marcel Dekker, New York 2002.

Wang P., Zhang X., Kong C.: The response of allelopathic rice growth and microbial feedback to barnyard grass infestation in a paddy field experiment. - Eur. J. Soil Biol. 56: 26-32, 2013.

Wu W., Cheng S.: Root genetic research, an opportunity and challenge to rice improvement. - Field Crop Res. 165: 111124, 2014

Yang C.M., Yang L.Z., Yang Y., et al..: Rice root growth and nutrient uptake as influenced by organic manure in continuously and alternately flooded paddy soils. - Agric. Water Manag. 70: 67-81, 2004.

Yang J.C.: [Relationships of rice root morphology and physiology with the formation of grain yield and quality and the nutrient absorption and utilization.] - Sci. Agr. Sin. 44: 36-46, 2011. [In Chinese]

Zhang J.L., Wu S., Shi X.G. et al.: [Influence of barnyard grass (Echinochloa crusgalli) on the growth of double cropping paddy rice and its economic threshold.] - Acta Prata. Sin. 24: 44-52, 2015. [In Chinese]

Zhang L., Zhang L., Sun J. et al: Rubisco gene expression and photosynthetic characteristics of cucumber seedlings in response to water deficit. - Sci. Hortic. 161: 81-87, 2013.

(C) The authors. This is an open access article distributed under the terms of the Creative Commons BY-NC-ND Licence. 